\title{
Competitiveness of Indonesian Shrimp Export to the United States
}

\author{
Lim Sanny ${ }^{1 *}$; Darma Kusuma²; Martinus Evan Willyanto ${ }^{3}$ \\ ${ }^{1}$ Business Management Program, BINUS Business School Master Program, Bina Nusantara University \\ Jln. K. H. Syahdan No. 9, Jakarta Barat 11480, Indonesia \\ ${ }^{2,3}$ Management Department, BINUS Business School Undergraduate Program, \\ Bina Nusantara University \\ Jln. K. H. Syahdan No. 9, Jakarta Barat 11480, Indonesia \\ ${ }^{1} 1$ sanny@binus.edu; 22darma.kusuma@binus.ac.id; ${ }^{3}$ martinus.evan@binus.ac.id
}

Received: $28^{\text {th }}$ November 2019/ Revised: $20^{\text {th }}$ August 2020/ Accepted: $20^{\text {th }}$ October 2020

How to Cite: Sanny, L., Kusuma, D., \& Willyanto, M. E. (2021). Competitiveness of Indonesian Shrimp Export to the United States. Binus Business Review, 12(2), 103-112. https://doi.org/10.21512/bbr.v12i2.6144

\begin{abstract}
Agricultural sector in Indonesia contributes greatly to employment, foreign exchange earners, and economic growth. In the export sector, shrimp commodities have the largest portion and become Indonesia's leading commodities. However, Indonesia still cannot become a leader in the world's largest shrimp exporter and only occupies the fourth position of the world's shrimp exporter. There were two goals in the research. First, it was to determine the position of the competitiveness of Indonesian shrimp commodity exports compared to other exporting countries in the United States market. Second, it determined the factors that affected the competitiveness of shrimp exports commodity and made business strategy recommendations for Indonesian shrimp commodities. The research used panel data with a cross-section of seven countries and time series from 2001 to 2017. The result shows that Indonesia has a competitive advantage in the United States market. However, Indonesia must be wary of Ecuador with a higher Revealed Comparative Advantage (RCA) Value and India, the lead exporter in the United States Market. The factors that affect the competitiveness of shrimp exports are Gross Domestic Product (GDP), population, economic distance, and exchange rate of shrimp exporting countries against the US dollar. Last, the right business strategy for Indonesia is to perform market penetration, market development, and product development strategies.
\end{abstract}

Keywords: export competitiveness, shrimp export, United States

\section{INTRODUCTION}

International trade is very important for every country, especially exports and imports (Abdullahi, Safiyanu, \& Soja, 2016). Indonesia is an agrarian country where the agricultural sector contributes greatly to employment, foreign exchange earners, and economic growth (Soviandre, Musadieq, \& Fanami, 2014). In the export sector of agriculture, shrimp commodities have the largest portion and become Indonesia's leading commodities (Ashari, Sahara, \& Hartoyo, 2016). One of the causes of the large export value of Indonesian fish and shrimp is the vast ocean and fisheries area.

According to the Ministry of Marine Affairs and
Fisheries Republic of Indonesia, Indonesia is the largest archipelago country in the world. Compared to other ASEAN countries, Indonesia is the country with the largest sea area (Kementrian Kelautan dan Perikanan Republik Indonesia, 2018). It has an area of sea waters of 5,8 million $\mathrm{km}^{2}$ (consisting of the territorial sea area of 0,3 million $\mathrm{km}^{2}$, archipelago water area of 2,95 million $\mathrm{km}^{2}$, and Exclusive Economic Zone (ZEE) of 2,55 million $\mathrm{km}^{2}$ ) (Nugroho et al., 2018). This fact can illustrate that the potential of Indonesian fisheries, especially shrimp, is very large. Hence, if it can be managed properly, and its activities can be sustainable, it will become one of the main sources of capital development in the present and future (Schouten, Vellema, \& Wijk, 2016). 
Shrimp occupies the first position of Indonesian fishery export commodities with an export value reaching US\$ 1,7 billion (38,7\%) in 2017 (Kementrian Kelautan dan Perikanan Republik Indonesia, 2018). It makes the shrimp commodity as the main and superior fisheries sub-sector (Wati, 2018). In addition, according to the Indonesian Ministry of Trade, shrimp is one of the main export commodities. It ranks the eighth from all commodities in Indonesia (Kementrian Perdagangan Republik Indonesia, 2019). Thus, shrimp commodities contribute significantly to economic growth and absorb a large workforce(Mohsin etal., 2017). Shrimp has a large role in the economic performance of Indonesian fisheries (Suhana, 2017). The value of Indonesian shrimp exports can be improved by increasing the performance of shrimp production and resource utilization, given the enormous potential that Indonesia has (Gusmawati et al., 2018).

Shrimp product trade increased in the 2012-2017 period. Based on data from the International Trade Center, in 2012, the trade value of shrimp products was only US\$ 11,2 billion and increased significantly to US\$ 18,2 billion in 2017. The average growth of shrimp trade value per year is $8 \%$ during this period (International Trade Centre, n.d.). In the international market, shrimp commodity is the second largest commodity in the trade value of fisheries products (Zhao et al., 2016). In 2016, the shrimp commodity trade value reached $16 \%$ of the world trade value in fisheries products (Food and Agriculture Organization of the United Nations, 2018). Hence, opportunities for market share for shrimp commodities will be more wide open because of the huge demand for shrimp products in the world (Yi, Reardon, \& Stringer, 2018).

The main international shrimp market is dominated by the United States and Japan (Haryotejo, 2013). The United States is the largest shrimp importer country. Its value of imports increased by $46,6 \%$ (US $\$$ 1,65 billion) from US $\$ 3,5$ billion to US $\$ 5,2$ billion in 2017. Meanwhile, Japan's import values experienced a decrease of $34,3 \%$ from US\$ 2,6 billion in 2002 to US\$ 1,7 billion in 2017. The value of global shrimp imports also increased from US\$ 11 billion to US\$ 18,2 billion in 2017 (International Trade Centre, n.d.). Indonesia must take advantage of the great demand for global shrimp imports (Muryani, Sari, \& Landiyanto, 2019), especially in the United States, which has the highest economic value. Then, that country will be an excellent opportunity for Indonesian shrimp exports.

Indonesia is one of the seven major shrimp exporters in the world. The others are India, Ecuador, Vietnam, Argentina, Thailand, and China (Khaliqi, Rifin, \& Adhi, 2018). Indonesia can increase domestic shrimp production because it has a large shrimp cultivation area (Wati, Chang, \& Mustadjab, 2013). The increase in the contribution of the seven countries' shrimp exports was from only $66,6 \%$ of the world export value (US\$ 5,2 billion) in 2002 to $75,5 \%$ (US\$ 13,6 billion). Thailand was the largest shrimp exporter in 2017, with an export value of US\$ 1,7 billion. However, in the same year, Thailand's position was shifted to India, which became the largest shrimp exporter country with an export value of US\$ 4,6 billion (International Trade Centre, n.d.).

With its great potential, Indonesia is still unable to become the leader in the world's largest shrimp exporter. It is only able to occupy the fourth position of the world's shrimp exporter. Thus, competitiveness needs to be improved to face increasingly competitive regional and global competition. Competitiveness can be seen in the country's ability to compete with its advantages (Mufa'ah and Hayati, 2016). Competitiveness is determined by a country's productivity by using natural, human, and capital resources. Basically, it is needed to improve the standard, quality of life, and existence of the economy to be more market-oriented. The World Economic Forum (WEF) also emphasizes that economic competitiveness in an integrated world determines how a country converts the created potential by global market access into opportunities for companies and their communities (World Economic Forum, 2015).

Competitiveness is an essential factor because it will always be used by companies and industries to conduct business activities, especially in producing goods and services to meet market demand (Gupta, Malhotra, Czinkota, \& Foroudi, 2016). Various parties and many experts have provided definitions of competitiveness. The concept of competitiveness is not initially an economic concept but a political and business concept. To improve it, company and industry performance cannot be separated into two terms: comparative and competitive advantage. The comparative advantage of each country will determine what happens when there is trade between them (Wati et al., 2013).

Meanwhile, competitive advantage is defined as, "An ongoing ability to gain profits and maintain market share in the domestic and international markets" (Simanjuntak, Arifin, \& Mawardi, 2017). The value that customers place on a product reflects the utility they get from the product. In other words, it is the obtained happiness or satisfaction from consuming or owning the product. Then, the value must be distinguished from price. It is something the customer receives from a product. It is a function of product attributes, such as performance, design, quality, and point-of-sales, and after-sales services (Wang \& Ming, 2018).

The research of competitiveness, especially in shrimp products, is still limited. The research is very important in identifying Indonesia's position among competing countries and evaluating the Indonesian shrimp commodity in the main market. It involves the variables in the Gravity model to determine the factors that influence the competitiveness of shrimp commodities. For economic variables, the used variables are Gross Domestic Product (GDP) of Indonesia and competing shrimp commodity export countries, economic distance, and the exchange rate of the exporting country's currency to the United States. Meanwhile, for non-economic variables, the variables 
are the population of Indonesia and competitor countries for shrimp commodity exports.

The Gravity model has become one of the most successful empirical models in economic modeling (Falk, 2016). The model is used to explain bilateral trade flows using statistical methods. It divides the economic size between two countries represented by GDP with the distance between trade centers between the two countries (Morley, Rosselló, \& SantanaGallego, 2014). The model analyzes the economic and non-economic factors that affect trade between two countries based on Newton's law of gravity (Wiranthi, Aminudin, \& Dewi, 2019). The formulation of the model is adopted from Newton's general equation of gravity in physics. The equation of the Gravity model is in Equation (1) (Kabir, Salim, \& Al-Mawali, 2017). It shows $F$ for trade flow, $G$ for constant, $M$ for economic dimensions, and $\mathrm{D}$ for distance.

$$
F_{i j}=\frac{\left(G \times M_{i} \times M_{j}\right)}{D_{i j}}
$$

As one of the main variables in the Gravity model trade flow analysis, Gross Domestic Product (GDP) shows the size of a country's economic capability. It describes the state of a country's economy because it involves the amount of consumption, investment, and government purchases. According to Zheng, TuckerDrob, and Briley (2019), it is the number of products and services produced by a country in one year. It is used to measure the total value of a country's goods and services without differentiating the citizenship.

In the research, the used exchange rate is currency value of the exporting country per US dollar. It is because world trade transactions use the US dollar, and the main shrimp market for the research is the United States. If the estimation results show a positive sign, there will be a depreciation of the exporting country's currency against the US dollar. Vice versa, negative signs in the estimation results indicate appreciation.

Next, distance is a geographical factor. It is the main variable in the Gravity model for the analysis of bilateral trade flows (Gilardoni, Reguzzoni, \& Sampietro, 2016). This variable is an indication of the transportation costs faced by a country in exporting. The longer the distance is, the greater the transportation costs and the lower the export value will be. Economic distance is obtained based on the formula from Santana-Gallego, Ledesma-Rodríguez, and Pérez-Rodríguez (2016), as shown in Equation (2). It has $\mathrm{JG}_{\mathrm{ij}}$ as the geographical distance between

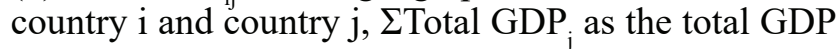
of country $\mathrm{j}$ in the observation period, and $\mathrm{GDP}_{\mathrm{jt}}$ as GDP of country $j$ in year $t$.

$$
\text { Distance }=J G_{i j} \times \frac{\left(\sum{\text { Total } \left.G D P_{j}\right)}\right.}{G D P_{j t}}
$$

Countries with a strong consumer level require an increase in production capacity so that domestic demand increases due to an increase in GDP. GDP of exporting countries and economic distance have a significant and negative influence on Indonesian shrimp exports (Sitompul, Sahara, \& Anggraeni, 2018). Meanwhile, the exchange rate has a significant and negative effect, but the population has a significant and positive influence on Indonesian exports (Wiranthi et al., 2019).

There are two goals in the research. First, it is to determine the position of competitiveness of Indonesian shrimp commodity exports compared to other exporting countries in the United States market. Second, it determines the factors that affected the competitiveness of shrimp exports commodity and make business strategy recommendation for Indonesian shrimp commodities.

\section{METHODS}

The type of data used in the research is secondary data. The data are collected using a literature review to get the needed information. Meanwhile, the data analysis method consists of Revealed Comparative Advantage (RCA) to determine the level of shrimp export competitiveness using Microsoft Excel 365 and panel data regression to determine the factors that influence the level of shrimp export competitiveness using Stata 14. Moreover, there are five hypotheses in the research, as clarified and seen in Figure 1.

H1: There is a significant positive effect between the exchange rate of the exporting country and the United States on the level of shrimp export competitiveness.

$\mathrm{H} 2$ : There is a significant negative influence between the GDP of Indonesia and competing countries on the level of shrimp export competitiveness.

H3: There is a significant negative influence between the population of Indonesia and competing countries on the level of shrimp export competitiveness.

H4: There is a significant positive influence between the economic distance of the exporting country and the United States on the level of shrimp export competitiveness.

H5: There is a significant influence between the exchange rate of the exporting country with the United States, the GDP of Indonesia and competing countries, the population of Indonesia and competing countries, and the economic distance of the exporting country and the United States on the level of competitiveness of shrimp exports. 


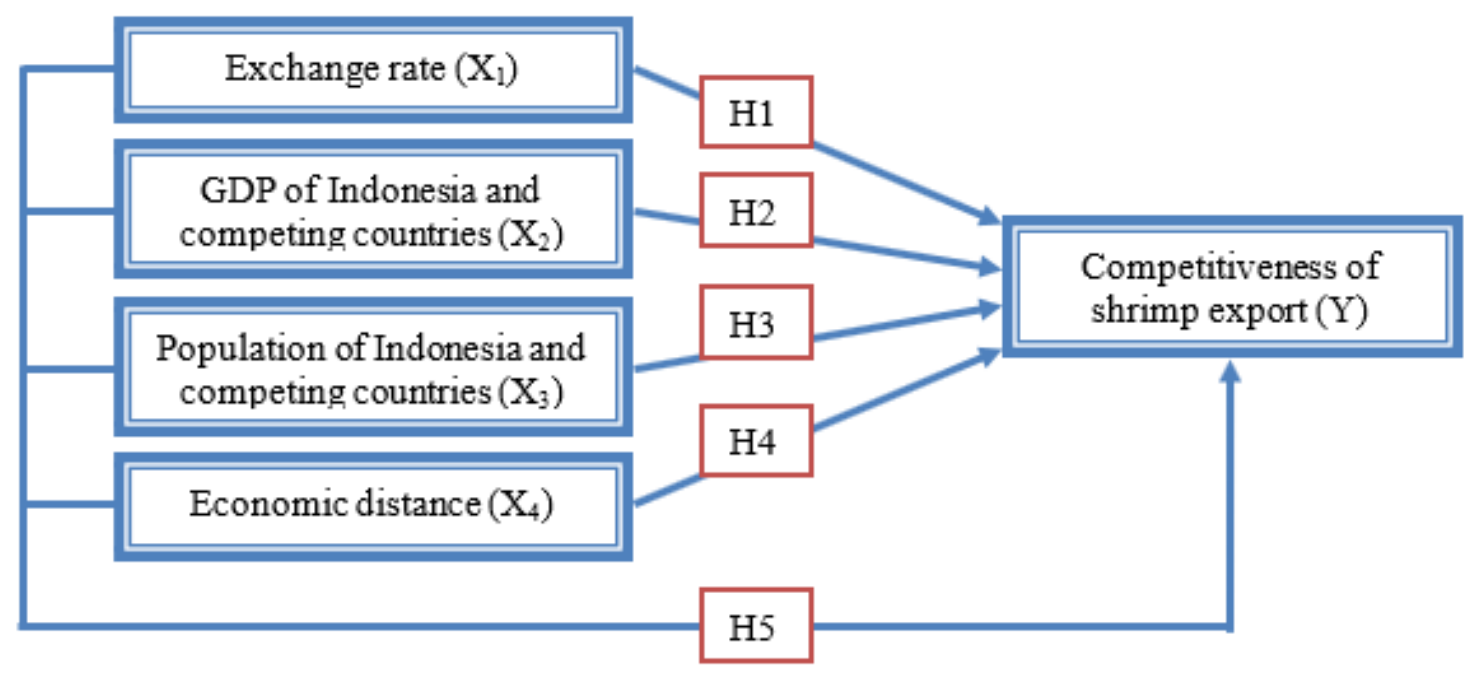

Figure 1 Research Model

Table 1 The Calculation Results of RCA Value

\begin{tabular}{cccccccc}
\hline Year & Indonesia & Vietnam & Thailand & China & India & Ecuador & Argentina \\
\hline 2001 & 4,84 & 113,99 & 27,05 & 0,59 & 8,56 & 34,84 & 2,96 \\
2002 & 5,17 & 64,78 & 21,88 & 0,79 & 10,30 & 29,48 & 2,64 \\
2003 & 5,69 & 41,54 & 21,57 & 0,95 & 10,28 & 24,30 & 1,35 \\
2004 & 12,07 & 27,68 & 19,63 & 0,67 & 9,05 & 18,90 & 0,12 \\
2005 & 13,63 & 28,76 & 22,30 & 0,38 & 7,54 & 20,88 & 0,00 \\
2006 & 13,93 & 21,18 & 25,28 & 0,51 & 5,15 & 19,96 & 0,03 \\
2007 & 15,05 & 20,36 & 27,08 & 0,36 & 4,09 & 24,49 & 0,30 \\
2008 & 19,80 & 18,13 & 27,75 & 0,38 & 2,82 & 18,77 & 0,12 \\
2009 & 15,17 & 12,28 & 29,02 & 0,33 & 3,19 & 24,99 & 0,17 \\
2010 & 12,89 & 14,66 & 29,59 & 0,33 & 4,60 & 23,80 & 0,25 \\
2011 & 15,14 & 12,26 & 29,39 & 0,31 & 6,14 & 23,15 & 0,76 \\
2012 & 19,98 & 10,51 & 16,95 & 0,10 & 8,80 & 36,75 & 0,93 \\
2013 & 21,82 & 10,22 & 9,68 & 0,08 & 12,33 & 29,98 & 1,86 \\
2014 & 24,55 & 9,45 & 5,94 & 0,06 & 12,39 & 35,38 & 4,49 \\
2015 & 23,15 & 5,56 & 5,92 & 0,04 & 14,18 & 42,79 & 5,75 \\
2016 & 22,45 & 4,37 & 7,25 & 0,07 & 14,72 & 44,18 & 6,91 \\
2017 & 21,03 & 2,99 & 5,92 & 0,09 & 18,59 & 39,29 & 10,94 \\
Average & 15,67 & 24,63 & 19,54 & 0,36 & 8,99 & 28,94 & 2,33 \\
\hline
\end{tabular}

\section{RESULTS AND DISCUSSIONS}

Based on Table 1, the RCA value for shrimp commodities in 2001-2017 shows that Indonesia has a bigger RCA value than 1 . Therefore, Indonesia has a competitive advantage in the United States market because there is no RCA value of $<1$. From the average value of RCA from 2001-2017, Indonesia has a smaller average RCA value compared to Vietnam,
Thailand, and Ecuador. However, in the last five years, the value of RCA Indonesia ranks second. It only loses to Ecuador. Meanwhile, the third rank is India. Based on these results, Indonesia has a competitive advantage over shrimp commodities in the United States market, but there is still strong competition between Indonesia, Ecuador, and India. The results can also be seen in Figure 2. 


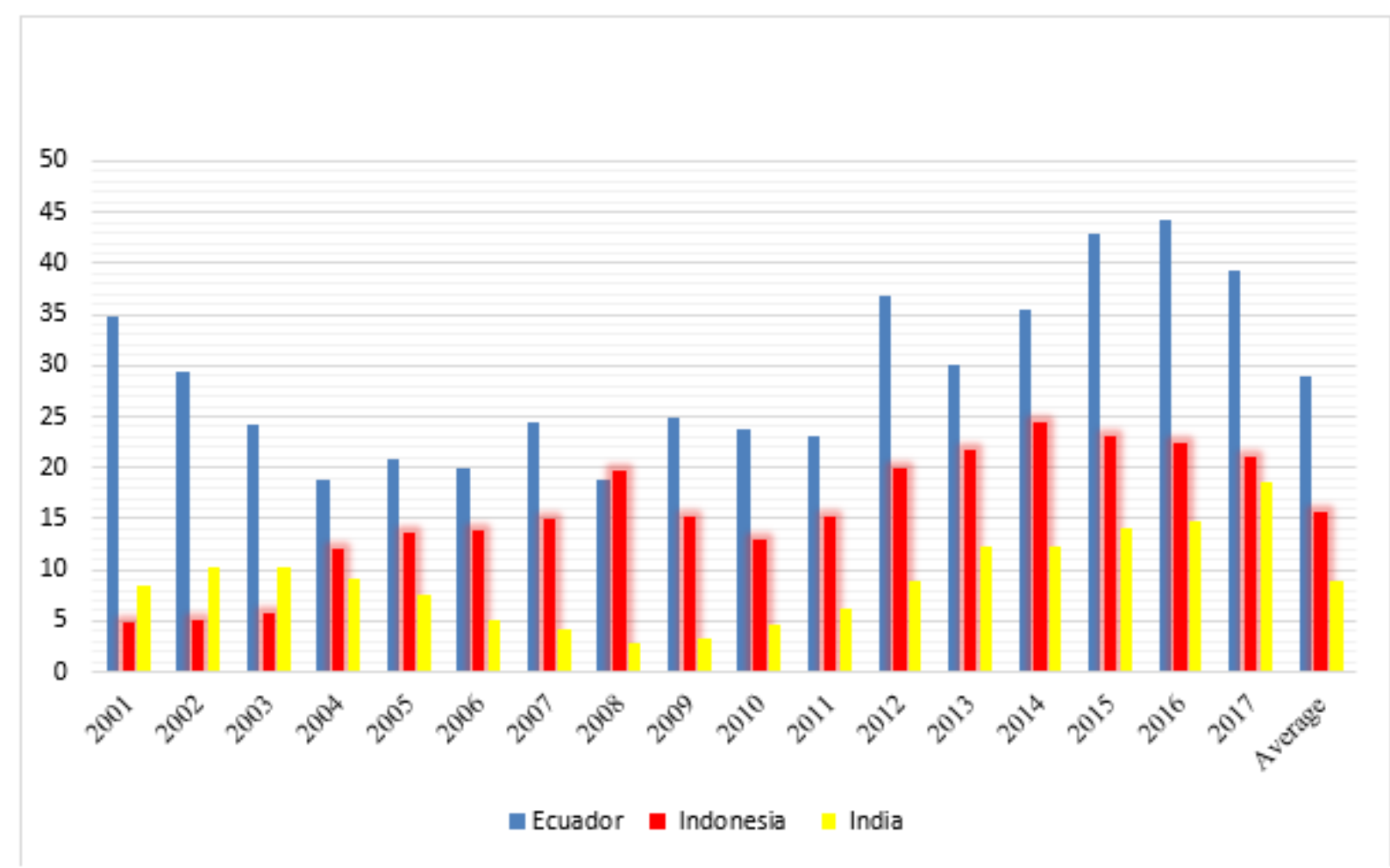

Figure 2 RCA Value of Major Competitor Countries of Shrimp Exports in the United States

The high competitive advantage of Ecuadorian shrimp exports in the United States is because the United States is the main destination. Shrimp production in Ecuador has experienced a large increase since the beginning of the $20^{\text {th }}$ century. It is due to an increase and the implementation of technologies and production systems that are more environmentally friendly. Hence, it increases the productivity of the shrimp sector in Ecuador. Besides technology, Ecuador has several advantages, such as relatively cheap labor, shrimp in the form of larvae that tend to have good resistance to disease, shrimp industry players in Ecuador want to share knowledge to grow together, a good climate for production, involvement of the Ecuadorian government in protecting its shrimp industry, and Ecuador's excellent shrimp quality. The quality of Ecuadorian shrimp is demonstrated by the very good quality control system following the demands of the Food and Dietary Supplements (FDA), Veterinary Department of the European Union, Japanese Organizations for Consumer's Protection, and the Canadian Inspection Organization (Schwarz, n.d.).

On the other hand, the government plays an essential role in the progress of shrimp and other fishery product exports in India. The Indian government provides various subsidies in the form of financial assistance to buy refrigerated trucks, organizes refrigeration storage, and purchases antibiotic testing equipment and insurance protection for workers (Nicholas, Maheswaran, \& Gunalan, 2015). Moreover, exporters are facilitated with assistance in the form of export promotion, research and development, sanitation and hygiene, and adequate port infrastructure and facilities.

Meanwhile, the development of competitiveness of Indonesian shrimp in the United States also tends to fluctuate over the past ten years. The competitiveness of shrimp export can drop at any time if it is not properly maintained. Indonesia, which has more potential, must pay attention to and be aware of competition from Ecuador and India. The superiority of human and natural resources must be utilized to increase the production and quality of exported shrimp products. Strengthening shrimp exports can be done by developing infrastructure throughout Indonesia so that there is no inequality, and it encourages national shrimp producers to use modern or intensive agricultural practices. Subsidies and assistance from the government in the form of capital assistance and the availability of research and development provide convenience for shrimp exporters. After knowing the position of competitiveness of Indonesian shrimp products in the United States market, the next step is to look for factors that influence the competitiveness.

To find out the factors that influence shrimp export competitiveness, the analysis conducted is panel data regression. The analysis begins by selecting an estimation model of panel data regression. First, Chow test determines the fixed effect or common 
effect of the model that is most appropriate to use in estimating panel data. From the result, Prob. $>\mathrm{F}$ is 0,000 . It is lower than $\alpha(5 \%)$, so the decision is to accept the hypothesis. This result shows that the model estimation is a Fixed Effect Model (FEM).

Second, the Hausman test compares the best estimation model from the fixed effect and random effect model. Based on the Hausman test, the best estimation model is FEM with Prob. > chi2 value of 0,0008 . It is lower than $5 \%$, so the decision is to accept the hypothesis.

After knowing the estimation model is FEM, the following test is to determine whether the residual structure variance-covariance is homoscedastic or heteroscedastic and there is a cross-sectional correlation or not. First, to determine whether the residual variant-covariance structure is homoscedastic or heteroscedastic, a Wald test is performed. Based on the modified Wald test for heteroscedasticity, Prob. $>$ chi 2 value is 0,000 . It is less than $\alpha(5 \%)$, so the decision to accept the hypothesis. The result shows that the residual variance-covariance structure of the model is heteroscedastic.

After that, the next test to know whether there is a cross-sectional correlation in this heteroscedasticity model or not. The test to know the cross-sectional correlation in this variance-covariance residual model of FEM in heteroscedasticity model is the BreushPagan Lagrange Multiplier test. The test obtains a statistical value of $109,2>\mathrm{X} 20,05 ; 21=32,67$. Hence, the residual variance-covariance structure of the FEM model is heteroscedastic. Moreover, there is a crosssectional correlation. The most appropriate method for estimating the parameters of the FEM is Feasible Generalized Least Square (FGLS). FGLS is estimated using the Generalized Least Square (GLS) method, so testing classical assumptions is not required.

Table 2 FGLS Regression Results

\begin{tabular}{cccc}
\hline Variable & Coefficient & T-Statistic & Probability \\
\hline GDP & $-0,000432$ & $-9,11$ & 0,000 \\
Population & $-0,009825$ & $-27,16$ & 0,000 \\
Economic Distance & $7,72 \mathrm{e}-06$ & 6,26 & 0,001 \\
Exchange Rate & 0,000188 & 3,48 & 0,000 \\
C & 16,28802 & 34,4 & 0,000 \\
Prob (F-statistic) & 0,000 & & \\
\hline
\end{tabular}

Based on the results of data processing using STATA 14 in Table 2, it can be seen that the probability value for $\mathrm{F}$-statistics is 0,000 . This value is smaller than the $\alpha$ value of $5 \%$, so that hypothesis is accepted. It can be concluded that there is a significant simultaneous influence between the GDP of the exporting country, exporter population, economic distance, and exchange rates on the competitiveness of the shrimp exporting country. $\mathrm{H} 5$ is accepted. Moreover, the coefficient value is very small, so that the research uses the logarithmic function to improve the value of the coefficient value. Table 3 shows the results of the logarithmic functions that have been applied to the data.

Table 3 FGLS Regression Results (Log)

\begin{tabular}{cccc}
\hline Variable & Coefficient & T-Statistic & Probability \\
\hline GDP & $-1,60$ & $-6,36$ & 0,000 \\
Population & 0,935 & 3,71 & 0,000 \\
Economic Distance & $-1,22$ & $-4,24$ & 0,000 \\
Exchange Rate & 0,15 & 3,14 & 0,002 \\
C & 11,11 & 6,75 & 0,000 \\
Prob (F-statistic) & 0,000 & & \\
\hline
\end{tabular}

Based on the results in Table 3, the coefficient value appears to have increased from Table 2 in the variables of GDP, population, economic distance, and exchange rate. Based on the results, the GDP of the exporting country has a significant influence on the competitiveness of shrimp exporting countries and shows the direction of the negative coefficient. Thus, the increase in the real GDP of the exporting country will reduce the level of competitiveness of the shrimp exporting country. $\mathrm{H} 2$ is accepted. A country with a strong consumer level requires an increase in production capacity so that domestic demand also increases due to an increase in GDP (Sitompul et al., 2018). This result is supported by the statement of Muharami and Novianti (2018). An increase in GDP encourages people to consume more goods so that demand for goods will increase. Therefore, an increase in the GDP of the exporting country will increase the purchasing power of the domestic community so that the shrimp export capacity to foreign countries decreases. In other words, shrimp market share will decrease in destination countries, resulting in a decline in the competitiveness of shrimp exporting countries.

The population has a significant influence on the competitiveness of shrimp exporting countries and shows the direction of the negative coefficient. Thus, the increase in the population of the exporting country will reduce the country's competitiveness. H3 is accepted. The growth of the population of the exporting country will increase production capacity, labor force, and export supply. On the other hand, the population also has an impact on the demand for domestic goods. In other words, domestic demand also affects exports. The dense population of exporting countries represents a large market size, which can also reduce pressure on sales to international markets. Hence, it reduces the dynamics of domestic companies and limits export development (Bui \& Chen, 2015). An increase in the population of the exporting countries shows that the country can meet the needs of its country. It is in line with the previous discussion that an increase in population will increase domestic consumption so that 


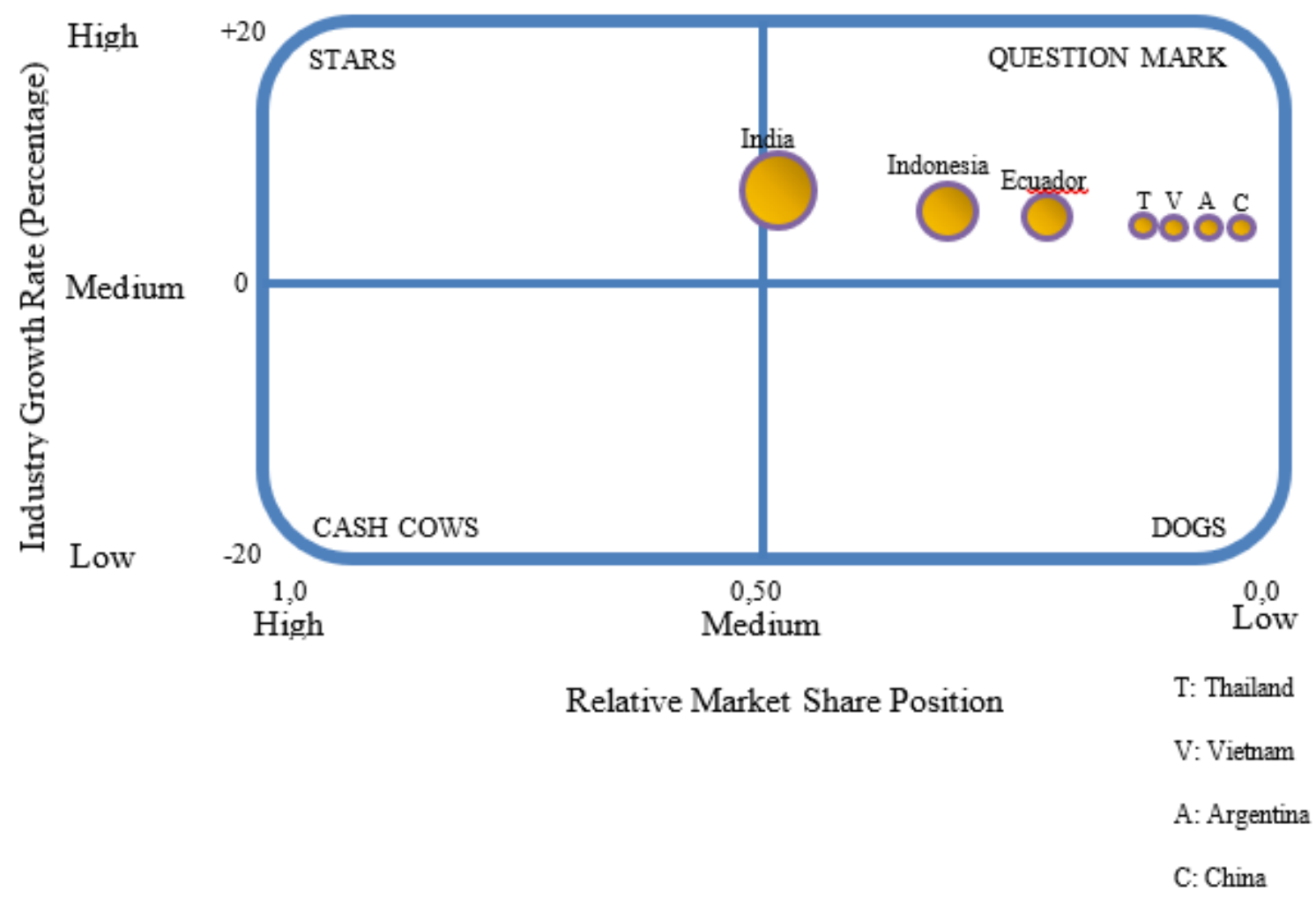

Figure 3 BCG Matrix of Indonesian Shrimp Commodities

the export capacity of abroad goods will decrease.

Then, the exchange rate has a significant effect on the competitiveness of shrimp exporting countries. It shows a positive coefficient direction. The results of the positive coefficient show the depreciation of the exchange rate of the exporting country's currency against the US dollar. The depreciation of the exchange rate of the exporting countries against the US dollar results in shrimp export prices in the United States market becoming cheaper. Then, the population of the United States will buy more shrimp products from exporting countries. H1 is accepted. When depreciation of the exchange rate of an exporter country occurs, the country's export value and export volume will increase (Kanaya \& Firdaus, 2014). The depreciation of the currency of the exporting country explains that the appreciation of the currency of the destination country causes the price of foreign products to be more expensive than the exporting country. It encourages importing countries to increase export demand for products from other countries that have relatively lower prices.

Next, economic distance has a significant effect on the competitiveness of shrimp exporting countries. It also shows positive coefficient signs. $\mathrm{H} 4$ is accepted. The distance in the estimated gravity is expected to decrease with the development of communication and technology. The possibility of distance variables in gravity regression is a proxy of several determinants in international trade and combines some of the effects of improvements in communication and technology (Baier, Kerr, \& Yotov, 2018). At present, various mass transportation methods have emerged. Those have been developed and are relatively cheaper because they can reduce the time and cost of transportation. Distance has a positive influence because the trading partner country is the main market for product commodities. If the two countries conducting international trade have large distances, the producer will increase exports to cover the fixed costs as the implications of the distance of export destinations are getting further (Carolina \& Aminata, 2019). Therefore, the further distance between the two countries will increase the value of exports which also increases the competitiveness of the exporting countries. In addition, the geographical proximity between the exporting country and the importing country will result in the shrimp product being traded of the same type. In other words, the countries, which should import shrimp products, can actually become competitors.

Next, the research determines the right business strategy for Indonesian shrimp commodities using an approach through the BCG matrix. In determining the quadrant position in the BCG matrix, it is necessary to calculate the rate of industry growth and relative market share. The shrimp industry in the United States has a high market growth. It is reflected in the value of the industry growth rate of $12,95 \%$. However, the relative 
market share value of Indonesian shrimp commodities in the United States has a relatively lower market share compared to India. Based on the value of the industry growth rate and the relative market share, the position of the quadrant of Indonesian shrimp commodities in the BCG matrix can be seen in Figure 3 .

The position of Indonesian shrimp commodities in the United States is currently in Quadrant I, Question Marks. It shows that the Indonesian shrimp commodity in the United States market has a relatively low market share, but it is an industry with high growth. By being a high-growth industry, Indonesian shrimp commodities in the United States market have a great opportunity to grow and develop to be successful as long as the availability of resources can be managed effectively and efficiently. Indonesia's strengths in its natural resources must be optimized to increase the competitiveness of shrimp commodities to become the market leader in the United States or even the world.

Based on the position of Indonesian shrimp commodities in the United States market, which are in the Question Marks in the BCG matrix and the factors that affect the competitiveness of Indonesian shrimp, relevant strategies can be formulated. The strategies can be used to improve the competitiveness of Indonesian shrimp commodities. There are market penetration, market development, and product development.

In the market penetration strategy, Indonesia must improve the ability of human resources, technology, and information related to the importance of shrimp commodity exports. It is related to the previous discussion that the GDP and population of shrimp exporting countries will reduce competitiveness due to high domestic consumption. Therefore, the government needs to provide socialization in the form of education to shrimp producers on the importance of exports for Indonesia.

In addition, Indonesia must increase market promotion by participating in or holding exhibitions of fishery products in export destination countries. By attending the exhibition, Indonesia can introduce and sell products directly to the target market. So, it can create brand awareness. The exhibition also allows Indonesian shrimp products to promote products to a broader group of consumers, such as groups of consumers who do not have or have little information about Indonesian shrimp products.

Then, the government is also expected to provide convenience to shrimp exporters by developing infrastructure, such as advice and infrastructure for transporting export goods. It aims to reduce the time and cost to export shrimp to destination countries with great distances from Indonesia. The stability of the Rupiah exchange rate against the US dollar also needs to be maintained. Although the depreciation of the exchange rate can increase the competitiveness of Indonesian shrimp, it is necessary to be aware of the negative impacts of inflation and reduce exports of other products.
Indonesia can implement a market development strategy by expanding the geographical segment of shrimp products. In addition to optimizing the potential of the United States as the main shrimp export destination country, Indonesia needs to expand its exports to non-traditional countries. For example, it can be the Middle East and South Africa.

Last, in product development strategy, Indonesia has to build many research and development centers to create superior quality shrimp products, add value, and increase competitiveness. On the other hand, the United States increasingly tightens the criteria and quality of imported fishery products in the United States. Shrimp producers in the country must also be equipped with knowledge about the increasingly stringent import policies of the destination country and certification of shrimp products to maintain competitiveness in the United States.

\section{CONCLUSIONS}

Based on the research results on the competitiveness of shrimp exporters in the United States market, there are several conclusions. First, using the RCA calculation, the value of the Indonesian RCA is always greater than one from 2001 to 2017. It shows that the Indonesian shrimp commodity has a competitive advantage in the main destination market, the United States.

Second, the variables of the GDP of the exporting country, the population of the exporting country, the exchange rate of the exporting country against the US dollar, and the economic distance between the exporting countries and the United States have a significant influence on the export competitiveness of the exporting country shrimp. It can also be seen that all independent variables in the research influence the competitiveness of shrimp exports partially and significantly. The GDP and population of the exporting country influence shrimp competitiveness significantly and negatively. Meanwhile, the exchange rate of the exporting country to the US dollar and economic distance have a significant and positive effect.

Third, based on the BCG matrix analysis, Indonesian shrimp commodities in the United States market are in the Question Mark quadrant. Thus, relevant strategies that must be used to improve competitiveness are incentive strategies. It includes the strategies of market penetration, market development, and product development.

Based on the results, suggestions can be given to related parties. The government should pay attention to GDP, population, exchange rates, and economic distance as the consideration in making policy. In addition, various recommended strategies are expected to be implemented to increase the competitiveness of Indonesian shrimp exports.

There is a limitation in the research. It only uses Harmonized System (HS) code shrimp, not specifically type of shrimp. So, for further research, 
it is expected to conduct research with HS Code in more specific shrimp products. It can also use the Revealed Symmetric Comparative Advantage (RSCA) as an alternative to the shortcomings of the RCA. Moreover, it can add other variables that can affect the competitiveness of shrimp exports to add insight and knowledge in the research of shrimp exports.

\section{REFERENCES}

Abdullahi, A. O., Safiyanu, S. S., \& Soja, T. (2016). International trade and economic growth: An empirical analysis of West Africa. IOSR Journal of Economics and Finance, 7(2), 12-15.

Ashari, U., Sahara, S., \& Hartoyo, S. (2016). Daya saing udang segar dan udang beku Indonesia di negara tujuan ekspor utama. Jurnal Manajemen \& Agribisnis, 13(1), 1-13. https://doi.org/10.17358/ jma.13.1.1

Baier, S. L., Kerr, A., \& Yotov, Y. V. (2018). Gravity, distance, and international trade. In Handbook of international trade and transportation. Edward Elgar Publishing.

Bui, T. H. H., \& Chen, Q. (2015). An analysis of factors influencing rice export in Vietnam based on gravity model. Journal of the Knowledge Economy, 8(3), 830-844. http://dx.doi.org/10.1007/s13132-0150279-y

Carolina, L. T., \& Aminata, J. (2019). Analisis daya saing dan faktor yang mempengaruhi ekspor batu bara. Diponegoro Journal of Economics, 1(1), 9-21.

Falk, M. (2016). A gravity model of foreign direct investment in the hospitality industry. Tourism Management, 55(August), 225-237. https://doi.org/10.1016/j. tourman.2016.02.012

Food and Agriculture Organization of the United Nations. (2018). Fishery and aquaculture statistics 2016. Rome: Food and Agriculture Organization of the United Nations.

Gilardoni, M., Reguzzoni, M., \& Sampietro, D. (2016). GECO: A global gravity model by locally combining GOCE data and EGM2008. Studia Geophysica et Geodaetica, 60(2), 228-247. https://doi.org/10.1007/ s11200-015-1114-4

Gupta, S., Malhotra, N. K., Czinkota, M., \& Foroudi, P. (2016). Marketing innovation: A consequence of competitiveness. Journal of Business Research, 69(12), 5671-5681. https://doi.org/10.1016/j. jbusres.2016.02.042

Gusmawati, N., Soulard, B., Selmaoui-Folcher, N., Proisy, C., Mustafa, A., Le Gendre, R., ... \& Lemonnier, H. (2018). Surveying shrimp aquaculture pond activity using multitemporal VHSR satellite images-Case study from the Perancak estuary, Bali, Indonesia. Marine Pollution Bulletin, 131(Part B), 49-60. https://doi.org/10.1016/j.marpolbul.2017.03.059

Haryotejo, B. (2013). Analisa diversifikasi pasar ekspor komoditi udang Indonesia. Jurnal Sosial Ekonomi Kelautan dan Perikanan, 8(1), 85-91. http://dx.doi. org/10.15578/jsekp.v8i1.1199
International Trade Centre. (n.d.). List of exporters for the selected product. Retrieved February $19^{\text {th }} 2019$ from https://www.trademap.org/Country_SelProduct TS.aspx

Kabir, M., Salim, R., \& Al-Mawali, N. (2017). The gravity model and trade flows: Recent developments in econometric modeling and empirical evidence. Economic Analysis and Policy, 56(December), 6071. https://doi.org/10.1016/j.eap.2017.08.005

Kanaya, I. A., \& Firdaus, M. (2014). Daya saing dan permintaan ekspor produk biofarmaka Indonesia di negara tujuan utama periode 2003-2012. Jurnal Manajemen \& Agribisnis, 11(3), 183-198.

Kementrian Kelautan dan Perikanan Republik Indonesia. (2018). Produktivitas perikanan Indonesia. Retrieved from https://kkp.go.id/wp-content/ uploads/2018/01/KKP-Dirjen-PDSPKP-FMBKominfo-19-Januari-2018.pdf

Kementrian Perdagangan Republik Indonesia. (2019). Perkembangan ekspor nonmigas (sektor). Retrieved February $20^{\text {th }} 2019$ from https://statistik.kemendag. go.id/growth-of-non-oil-and-gas-export-sectoral

Khaliqi, M., Rifin, A., \& Adhi, A. K. (2018). Trade effect of Sanitary and Phytosanitary (SPS) and Technical Barriers to Trade (TBT) on Indonesia's shrimp export. Indonesian Journal of Agricultural Research, 1(2), 134-141. https://doi.org/10.32734/ injar.v1i2.313

Mohsin, M., Mu, Y., Memon, A. M., Mehak, A., Shah, S. B. H., Kalhoro, M. T., \& Baset, A. (2017). Capture fisheries production and its economic role in Pakistan. Indian Journal of Geo-Marine Sciences (IJMS), 46(6), 1110-1115.

Morley, C., Rosselló, J., \& Santana-Gallego, M. (2014). Gravity models for tourism demand: Theory and use. Annals of Tourism Research, 48(September), 1-10. https://doi.org/10.1016/j.annals.2014.05.008

Mufa'ah, \& Hayati, M. (2016). Analisis daya saing ekspor komoditas udang Indonesia. Agrifo: Jurnal Agribisnis Universitas Malikussaleh, 1(1), 1-20.

Muharami, G., \& Novianti, T. (2018). Analisis kinerja ekspor komoditas karet Indonesia ke Amerika Latin. Jurnal Agribisnis Indonesia (Journal of Indonesian Agribusiness), 6(1), 15-26. https://doi.org/10.29244/ jai.2018.6.1.1-12

Muryani, Sari, D. R. \& Landiyanto, E. A. (2019). Competitiveness analysis and factors that influence the export of Indonesian shrimp commodities. Opcion, 35(22), 1417-1432.s

Nicholas, S. S. S., Maheswaran, M. L., \& Gunalan, B. (2015). Indian seafood industry strength, weakness, opportunities and threat in the global supply chain. International Journal of Fisheries and Aquatic Studies, 3(2), 199-205.

Nugroho, D., Kock-Larrouy, A., Gaspar, P., Lyard, F., Reffray, G., \& Tranchant, B. (2018). Modelling explicit tides in the Indonesian seas: An important process for surface sea water properties. Marine Pollution Bulletin, 131(Part B), 7-18. https://doi. org/10.1016/j.marpolbul.2017.06.033 
Santana-Gallego, M., Ledesma-Rodríguez, F. J., PérezRodríguez, J. V. (2016). International trade and tourism flows: An extension of the gravity model. Economic Modelling, 52(Part B), 1026-1033. https:// doi.org/10.1016/j.econmod.2015.10.043

Schouten, G., Vellema, S., \& Wijk, J. V. (2016). Diffusion of global sustainability standards: The institutional fit of the ASC-Shrimp standard in Indonesia. Revista de Administração de Empresas, 56(4), 411-423. https:// doi.org/10.1590/S0034-759020160405

Schwarz, L. (n.d.). National aquaculture sector overview: Ecuador. Retrieved June $10^{\text {th }} 2019$ from http://www. fao.org/fishery/countrysector/naso_ecuador/en

Simanjuntak, P. T. H., Arifin, Z., \& Mawardi, M. K. (2017). Pengaruh produksi, harga internasional dan nilai tukar Rupiah terhadap volume ekspor rumput laut Indonesia (Studi pada tahun 2009-2014). Jurnal Administrasi Bisnis, 50(3), 163-171.

Sitompul, T. K., Sahara, \& Anggraeni, L. (2018). The effects of trade facilitation on Indonesian fisheries export. Jurnal Manajemen \& Agribisnis, 15(3), 230-238. http://dx.doi.org/10.17358/jma.15.3.230

Soviandre, E., Musadieq, M., \& Fanami, D. (2014). Faktorfaktor yang mempengaruhi volume ekspor kopi dari Indonesia ke Amerika Serikat (Studi pada volume ekspor kopi periode tahun 2010-2012). Jurnal Administrasi Bisnis, 14 (2), 1-8.

Suhana. (2017). Jokowi dan ekonomi udang Indonesia. Retrieved from https:/ekonomi.kompas.com/ $\mathrm{read} / 2017 / 11 / 07 / 142435426 /$ jokowi-dan-ekonomiudang-indonesia?page $=$ all

Wang, P. P., \& Ming, X. G. (2018). Value evaluation method of industrial product-service based on customer perception. International Journal of Services Operations and Informatics (IJSOI), 9(1), 15-39. https://doi.org/10.1504/IJSOI.2018.088515

Wati, L. A. (2018). Analyzing the development of Indonesia shrimp industry. In IOP Conference Series: Earth and Environmental Science.

Wati, L. A., Chang, W. I., \& Mustadjab, M. M. (2013). Competitiveness of Indonesian shrimp compare with Thailand shrimp in export market. Wacana Journal of Social and Humanity Studies, 16(1), 24-31.

Wiranthi, P. E., Aminudin, I., \& Dewi, E. R. (2019). A gravity model for Indonesian canned tuna exports to the European Union market: An application of PPML Estimator. Sriwijaya International Journal of Dynamic Economics and Business, 3(1), 31-52.

World Economic Forum. (2015). The case for trade and competitiveness. Retrieved from http:// www 3.we for um.org/docs/WEF_GAC_ Competitiveness_2105.pdf

Yi, D., Reardon, T., \& Stringer, R. (2018). Shrimp aquacultural technology change in Indonesia: Are small farmers included? Aquaculture, 493, 436-445. https://doi.org/10.1016/j.aquaculture.2016.11.003

Zhao, H., Mai, W., Yun, J., Zhang, H., Chen, F., Huo, Q., \& Deng, J. (2016). Actualities and countermeasures of import shrimp in Zhanjiang. Journal of Food Safety and Quality, 7(8), 3407-3412.

Zheng, A., Tucker-Drob, E. M., \& Briley, D. A. (2019). National Gross Domestic Product, science interest, and science achievement: A direct replication and extension of the Tucker-Drob, Cheung, and Briley (2014) study. Psychological Science, 30(5), 776788. https://doi.org/10.1177/0956797619835768 